\title{
doispontos:
}

\section{As fontes democráticas do poder civil segundo Francisco Suárez}

\author{
The Democratic Sources of Civil Power According to Francisco Suárez
}

\author{
Alfredo Storck \\ alfredo.storck@ufrgs.br \\ Professor Titular do Departamento de Filosofia da UFRGS \\ Pesquisador do $\mathrm{CNPq}$
}

Resumo: O presente artigo tem por objetivo destacar o contexto no qual a obra Defensio Fidei de Francisco Suárez foi elaborada. Após salientar alguns elementos centrais dos debates entre partidários do direito divino dos reis e defensores da origem democrática do poder civil, veremos as linhas gerais do argumento avançado por Suárez para defender a origem democrática do poder civil e como ele interpreta essa tese.

Palavras-chave: Francisco Suárez, James I, origem do poder civil, direito divinos dos reis, democracia

\begin{abstract}
This article aims to highlight the context in which the work Defensio Fidei by Francisco Suárez was elaborated. After highlighting some key elements of the debates between supporters of the divine right of kings and defenders of the democratic origin of civil power, we will present the general lines of the argument advanced by Suarez to defend the democratic origin of civil power, and how he interprets this thesis.
\end{abstract}

Keywords: Francisco Suárez, James I, origin of civil power, divine right of kings, democracy 


\title{
1. Introdução
}

A longa história de disputas entre as monarquias europeias e a Igreja católica começa ainda na Idade Média e adentra o período moderno. Suas raízes mais antigas estão ligadas ao modo de funcionamento das instituições jurídicas sendo possível, de modo muitíssimo simplificado, identificar dois períodos. Um primeiro, caracterizado pelo processo de centralização legislativa da parte do poder real. Trata-se do período mais próximo ao final da Idade Média em que as cortes reais, inicialmente atuando de forma pontual na administração da justiça, pautam sua atuação em uma forma de direito que havia sido desenvolvido nas universidades, o ius commune. Progressivamente, esse modelo de decidir através da administração da justiça passa a dar lugar a um modelo de criação legislativa por meio de ordenanças, o que conduz, no século XVI, à tentativa de submeter inclusive as cortes eclesiásticas ao poder legislativo e decisório das cortes reais. O segundo período caracteriza-se pela reação da Igreja através de novas doutrinas acerca da legislação. Configura-se como uma tentativa de remoção da atividade legislativa das cortes reais por meio da criação de novos fora, com especial relevo para as noções de lei natural, forum internum e ênfase em direitos naturais que limitavam o poder legislativo dos monarcas. Importa-nos destacar aqui a criação do forum internum como domínio da consciência ou do pecado. (PROSPERI, 1996; LEITE, 2002; DECOCK, 2011). Esse forum estava associado à relação com Deus e ao sacramento da penitência. O forum externum, por sua vez, dizia respeito às faltas cometidas contra a sociedade e reprimidas pela jurisdição eclesiástica ou civil. Como todo católico estaria submetido à jurisdição do forum internum, mesmo as consciências dos reis poderiam ser julgadas por seus confessores e os monarcas poderiam ser ou não absolvidos por terem praticado certos atos.

Salientemos ainda nesse movimento a ideia de limitação do poder real por meio de direitos. O ponto é perfeitamente resumido por um importante historiador do direito romano e moderno.

\begin{abstract}
Durante o curso do século XVII, os direitos civis, a herança mais importante do Direito romano, era cada vez mais considerada como os direitos privados do indivíduo que transcendiam as jurisdições nacionais. Para conhecer esses conteúdos, o Corpus iuris era investigado. (...) O reflorescimento do Corpus iuris e do Direito romano no período moderno era, portanto, a-histórico. Não se buscava uma doutrina legal antiga, mas um novo pensamento jurídico. Com o Corpus iuris, buscavam salvaguardar os direitos privados dos cidadãos. Neste processo, o direito de Justiniano desempenhou o mesmo papel do humanismo no século XVI (WAELKENS, 2015, p. 121).
\end{abstract}

Façamos dois comentários sobre a citação acima. Em primeiro lugar, note-se que, durante o século XVI, uma característica importante dos pensadores que atuavam internamente à Igreja Católica era o fato deles possuírem uma dupla formação: teológica e jurídica, a tal ponto que um tipo particular de literatura surge no período, a saber, obras intituladas De Iustitia et Iure, Da justiça e do direito. Esse verdadeiro gênero literário adotava a forma de comentários à Suma de Teologia de Tomás de Aquino, mas representava, de fato, novas peças de criação e debates legislativos, uma vez que a autoridade dos teólogos fornecia, em última instância, os parâmetros de julgamento a serem empregados em escrutínios do forum internum. Por serem juristas formados muitas vezes tanto no direito civil quanto no eclesiástico, esses teólogos-juristas, para retomar aqui uma formulação já clássica, recorriam ao Corpus iuris ciuilis para encontrar formulações de direito dotadas de autoridade que somente uma fonte como essa poderia conferir. Todavia, essa fonte era reinterpretada de acordo com uma concepção de pessoa moral afeita aos moldes do cristianismo (STORCK, 2019). Assim, o Corpus iuris ciuilis passava a ser lido como verdadeiro depositório de direitos universais que promovia a liberdade e igualdade natural de todos os seres humanos. Não surpreende, portanto, que boa parte desses teóricos enfaticamente sustentará que todos os homens nascem naturalmente livres e iguais por terem sido criados por Deus (MÄKINEN, 2008). 
Em segundo lugar, não buscaremos, de forma alguma, justificar o uso a-histórico como método de interpretação do Corpus iuris ciuilis e tão pouco minimizar as críticas por escolas históricas ao método empregado pelos teólogos-juristas. O objetivo é exclusivamente o de apontar para a função retórica que desempenhava essa estratégia interpretativa. Por ser uma compilação legal revestida de autoridade histórica milenar e por veicular certos ideais de igualdade e liberdade que possibilitavam interpretações universalizantes, o Corpus iuris ciuilis oferecia campo fértil para autores que buscavam defender uma teoria acerca de direitos universais. Se quisermos, no entanto, buscar as verdadeiras raízes dessas teorias, não as encontraremos no próprio Corpus iuris ciuilis, mas na tradição do direito canônico. Aliás, um aspecto que tem sido bastante realçado nas últimas décadas é precisamente a importância que desempenhou o Corpus iuris canonici para o desenvolvimento do direito ocidental medieval e moderno (DECOCK, 2012).

Nosso objetivo nesse artigo será o de circunscrever o pensamento de Francisco Suárez no contexto desse debate. Para tanto, iniciaremos apresentando rapidamente o conflito envolvendo papistas e defensores do direito divino dos reis na Inglaterra no final do século XVI e início do XVII. Em seguida, apresentaremos rapidamente algumas das ideias centrais de Suárez acerca da origem democrática do poder civil, esperando deixar clara a importância do autor para a formulação de algumas teses mais características do pensamento político da época.

\section{Patriarcas e papistas}

Em sua obra póstuma destinada a defender o poder natural dos reis, Robert Filmer denuncia uma perigosa opinião que desfrutaria de grande reputação à época, a saber:

\footnotetext{
A humanidade nasceu e é naturalmente livre (freedom) de toda sujeição tendo liberdade (liberty) para escolher a forma de governo que lhe agradar e que o poder (power) que um homem tem sobre outros foi inicialmente atribuído de acordo com a desejo da multidão (FILMER, 1949, p. 53).
}

Aos olhos de pensador inglês, a tese teria surgido nas escolas de teologia e seria promovida por papistas, mais especificamente por pensadores ligados à Companhia de Jesus, como Robert Persons (1546-1610). Ainda que humanistas, como o historiador escocês George Buchanan (1506-1582) ou mesmo o próprio Calvino (1509-1564), endossassem a tese, sua principal formulação seria encontrada na obra do cardeal italiano Roberto Bellarmino (1542-1621). Filmer oferece, então, ao seu leitor uma passagem do De Laicis:

\footnotetext{
O poder secular ou civil (civic power/politica potestas ${ }^{1}$ ), diz ele, é instituído pelos homens e permanece no povo (people/in tota multitudine) a menos que seja atribuído a um Príncipe. Esse poder está imediatamente na multidão como seu sujeito; pois esse poder ela o tem por Lei Divina (Divine Law/jus divinum), mas a Lei Divina não o deu a nenhum homem em particular. Caso a lei positiva (positive law/jus positivum) fosse removida, não haveria razão para que em uma multidão (em que são iguais) um e não outro governasse sobre os demais. O poder é dado pela multidão a um homem ou a mais de um pela mesma lei da natureza (law of nature/jus naturae ${ }^{2}$ ), pois a república (commonwealth/respublica) por si só não pode exercer esse poder (power/potestas) e, portanto, deve conferi-lo a um ou a alguns homens. Isso depende do consentimento da multidão para ordenar acima de si mesma um Rei, um cônsul ou outro magistrado. E caso haja causa legítima, a multidão pode alterar o reinado em uma aristocracia ou democracia (FILMER, 1949, p. 53).
}

\footnotetext{
${ }^{1}$ Os termos em língua inglesa são de Filmer. Em latim, fornecemos a terminologia empregada por Bellarmino.

${ }^{2} \mathrm{~A}$ equivalência, empregada por Filmer, entre Divine law e law of nature é permitida pelo próprio cardeal: "At jus naturae est jus divinum" (BELLARMINO, 1721, p. 300b).
} 
Ainda que a citação acima seja, na verdade, um resumo do capítulo 6 do De Laicis ${ }^{3}$, ela captura bem a premissa central em que repousa a argumentação de Bellarmino: a liberdade natural de todos os seres humanos. É ela que permite concluir que, se os seres humanos são naturalmente livres, a autoridade política pertence a todos e a ninguém em particular. O poder político seria, por natureza, democrático e residiria imediatamente no povo, cabendo a esse decidir pelas formas de governo a adotar ou, havendo causa legítima, alterar a forma existente. Como bem mostrou Tutino, o projeto político de Bellarmino era o da construção de uma república cristã (respublica Christiana) capaz de fazer frente, por um lado, ao poder das igrejas protestantes e, por outro, posicionar-se frente à consolidação dos estados modernos nascentes (TUTINO, 2010). Tratava-se, portanto, de um projeto marcadamente pós-tridentino e que exigia da Igreja Católica a reelaboração dos principais dogmas teológicos de um catolicismo atacado pelas diversas formas de protestantismo e, simultaneamente, pela necessidade de defesa da instituição política do papado frente às novas estruturas estatais que surgiam na Europa. Quanto a esse segundo aspecto, Bellarmino encontrará uma esfera de atuação própria ao papado na divisão dos âmbitos de atuação dos poderes temporal e espiritual. O poder político dos reis é secular, ao passo que o poder da Igreja é sobrenatural. O principado temporal governa os homens enquanto são homens (regit homines ut homines) ao passo que o principado eclesiástico governa os homens enquanto são cristãos (regit homines ut Christiani). Será essa mesma divisão, que permite separar os âmbitos de atuação dos dois poderes, que acabará por estabelecer uma relação hierárquica entre as formas de governo. O império sobrenatural é o império das consciências e, nesse âmbito, o Papa goza de autoridade e jurisdição (TUTINO, 2010, p. 35-37). Como todas as consciências, mesmo a do rei, estão submetidas ao poder espiritual, ao guiar as consciências, o Papa poderá estabelecer limites para a ação dos católicos também em matéria temporal. Estão assim lançadas as bases para a famosa tese de Bellarmino sobre a potestas indirecta do sumo pontífice em matéria secular.

John Locke inicia o seu Primeiro Tratado sobre o Governo afirmando que a estratégia adotada por Filmer para defender a monarquia absoluta repousa justamente na negação daquela alegada nova opinião, uma vez que "a proposição em que alicerça todo o seu sistema é: Nenhum homem nasce livre" (LOCKE, 1998, p. 205). Locke também deixa claro que Filmer não era o único a defender essa tese:

Nesses últimos tempos, brotou entre nós uma geração de homens dispostos a adular os príncipes com a opinião de que têm eles um direito divino ao poder absoluto, sejam quais forem as leis pelas quais são constituídos e devem governar, ou as condições pelas quais chegaram ao poder, e por mais que seus compromissos de observar tais leis hajam sido ratificados por solenes juramentos e promessas. No intuito de abrir caminho para essa doutrina, negaram à humanidade o direito à liberdade natural (...) (LOCKE, 1998, p. 205).

Ao referir-se a "juramentos e promessas", Locke 4 está mencionando um outro elemento central para a compreensão da querela que opunha os defensores do direito divino dos reis e os partidários da origem democrática do poder civil. Já em 1598, James VI da Escócia (coroado James I da Inglaterra em 1603) havia tratado do assunto em seu The True Lawe of Free Monarchies: or, the reciprock and mutuall dutie betwixt a free King. Além de defender, por razões bíblicas, o direito divino dos reis, o monarca escocês sustenta que "pela lei da natureza, o Rei torna-se um Pai natural para todos os senhores feudais (lieges) quando de sua Coroação" (JAMES VI\&I, 2008, p. 195). A aparente metáfora paterna deve ser entendida em sentido literal, como James I faz questão de explicitar em seu discurso ao Parlamento em 1610. Pela coroação, transfere-se ao rei o tipo de poder que a lei natural, na tradição jurídica romana, atribuía ao pátrio poder, a saber, a potestas vitae et necis (poder de vida e morte) sobre seus filhos ou família (JAMES I, in WOOTON, 2003, p. 107). Esse poder absoluto sobre os súditos choca-se, como bem salientou Locke

${ }^{3}$ Para o original latino, consulte-se (BELLARMINO, 1721, p. 300b). Para a tradução inglesa do capítulo 6, consulte-se (BELLARMINO, 2012, p. 21-25).

${ }^{4}$ Sobre os aspectos teológicos do pensamento político de Locke, consulte-se: (GUY, 2020). 
na passagem supracitada, com aquele que deveria ser o momento ápice da coroação, o momento em que o rei presta juramento. Isso porque, pelo ato de prometer, o rei pareceria vincular-se a certas obrigações. Nas palavras do ainda James VI:

\begin{abstract}
E assim na coroação de nossos próprios reis, bem como na de todo Monarca Cristão, eles dão seu juramento, primeiramente de manter a religião presentemente professada no interior de seu país, de acordo com as leis onde elas estão estabelecidas, e de punir todos que aqueles busquem alterar ou perturbar sua profissão. Em seguida, de manter todas as leis boas e louváveis feitas pelos seus predecessores; vê-las executadas e punir quem as quebre ou viole, de acordo com a extensão da mesma. Finalmente, de manter todo o país e todo estado que possui em todos os seus antigos privilégios e liberdades, tanto contra inimigos externos como internos. (...) E esse juramento na Coroação é a mais clara, civil e fundamental lei, pela qual o ofício de rei é propriamente definido" (JAMES VI\&I, 2012, p. 194-195).
\end{abstract}

A tensão soa flagrante. De um lado, o rei possui poder absoluto, mas, de outro, élimitado por obrigações contraídas pelo próprio juramento. No entanto, o rei escocês acabará por enfraquecer a força do próprio juramento e irá na direção oposta à de Bellarmino ao dizer que nenhum povo tem o direito à rebelião, mesmo em se tratando de um rei tirano. Teria, contudo, o Papa esse direito por meio da potestas indireta aludida por Bellarmino? A resposta encontra-se na forma do célebre debate em torno do Juramento de Fidelidade. Após a frustrada tentativa de assassinato de James I em 1605, conhecida como a Conspiração da Pólvora, por um grupo de católicos ingleses, o Parlamento inglês adota, em 1606, o Oath of Allegiance exigindo que todos católicos ingleses jurassem fidelidade ao rei. Uma das cláusulas do juramento é destinada a expressamente limitar o poder papal sobre as consciências dos católicos ingleses:

Eu juro também que abomino do fundo meu coração, detesto e abjuro, como ímpia e herética a maldita doutrina e posição que os príncipes que são excomungados ou destituídos pelo Papa possam ser depostos e assassinados pelos seus súditos ou por qualquer outra pessoa. E acredito, e estou resoluto em consciência (conscience), que nem o Papa nem qualquer outra pessoa tenha poder (power) de me livrar desse juramento (McILWAIN, 1918, p. 74).

Sentindo-se atacado, o Papa Paulo V (1552-1621) reage por meio de dois Breves conclamando os católicos ingleses a não prestarem o juramento. Sem obter o efeito desejado, solicita ao cardeal Bellarmino escrever uma carta ao Arcebispo da Inglaterra, George Blackwell (1545-1613), criticando o juramento. ${ }^{5}$ Para o cardeal italiano, mais do que exigir a fidelidade civil ao rei da Inglaterra, o juramento conduziria a negar a primazia do poder da Santa Sé e isso precisamente por retirar do papado o poder sobrenatural sobre a consciência dos fiéis. Inicialmente, James I cogita deixar a resposta a cargo do Bispo de Winchester, Thomas Bilson (1547-1616). Posteriormente, indo contra à prática habitual de deixar a reposta a cargo de teólogos, o próprio James I tomará para si a tarefa de justificar a validade do juramento e publicará, primeiramente de forma anônima (1608) e depois reivindicando explicitamente a autoria e revisão do texto (1609) ${ }^{6}$, o Triplici Nodo, Triplex Cuneus: or, An Apologie for the Oath of Allegiance. James I sustenta que o juramento seria o único meio de separar os súditos leais e aqueles que não o são. Afirma, contra $o$ Papa, que Paulo V não teria conseguido demonstrar que o juramento seria contrário à fé católica e que a obediência ao poder temporal não é nem nunca foi vista como incompatível com a fé e a salvação das almas. Já a resposta a Bellarmino é mais incisiva. O cardeal é duramente atacado pela incongruência em seus escritos, por menosprezar o papel dos atentados contra a Rainha Elizabeth (1533-1603), por confundir a jurisdição espiritual do Papa com o juramento de fidelidade e por desconhecer o apoio indubitável dos antigos concílios em favor da supremacia temporal dos reis (BOURDIN, 2015, p. 190-191).

\footnotetext{
${ }^{5}$ Sobre a história do debate em torno do juramento de obediência, consulte-se: (a introdução de McILWAIN, 1918; TUTINO, 2007, cap. 5 e 6; TUTINO, 2010, cap. 4 e BOURDIN, 2015, o qual fornece em versão original e tradução francesa os principais textos do debate).

${ }^{6}$ Para uma análise da Apologie em suas duas versões e sobre como a autoria se faz presente em ambas, consulte-se (NORTH, 2012).
} 
Os debates crescem rapidamente em intensidade. Em 1610, o Papa Paulo V, por intermédio do cardeal Scipione Borghese, informa o então núncio papal de Madri, Decio Caraffa, que gostaria de ver Francisco Suárez (1548-1517) responder a James I. Por solicitação de Caraffa, Suárez, que ocupava à época a Cátedra Prima de Teologia em Coimbra, publica, em 1613, sua Defesa da Fé Católica contra os Erros da Seita Anglicana. Em dezembro do mesmo ano, a obra será queimada nas escadarias da Catedral de São Paulo em Londres e, após ser examinada pelo Parlamento de Paris, será igualmente queimada na Cidade Luz em junho de 1614.

\title{
3. Suárez e a defesa da fé católica
}

A importância de Suárez no debate inglês é evidenciada, mais uma vez, por Robert Filmer que inicia o capítulo XI do Patriarcha nos seguintes termos:

\begin{abstract}
Suárez, o jesuíta, levanta-se contra a autoridade real de Adão em defesa da liberdade do povo (freedom and liberty of the people) e argumenta assim: 'Pelo direito de criação (diz ele) Adão possuía apenas poder econômico (economical power), mas não político. Ele possuía poder sobre sua esposa e poder paterno sobre seus filhos, enquanto eles não fossem livres. Ele poderia também, nesse período, possuir servos e uma família completa, e nessa família ele poderia ter poder econômico total. Mas após as famílias começarem a se multiplicar e os homens a se separarem e tornarem-se chefes de diversas famílias, eles possuiriam o mesmo poder sobre suas famílias. Mas o poder político (political power) não começou até que as famílias começaram a reunir-se em uma comunidade perfeita (perfect community). Por conseguinte, como a comunidade não começou com a criação de Adão, nem apenas por sua vontade, mas com a de todos aqueles que concordaram nessa comunidade, então não podemos dizer que Adão naturalmente tinha a supremacia política nessa comunidade (FILMER, 1949, p. 74-75).
\end{abstract}

Fica evidente, na passagem acima, a diferença entre poderes econômicos (exercidos na casa pelo chefe da família) e políticos, um dos pilares da tese dos direitos divinos dos reis. Será justamente essa a diferença que conduz Filmer a afirmar contra Suárez: "Não sei o que ele entende por poder econômico total, nem como e em que ele real e essencialmente se distingue do político" (FILMER, 1949, p. 787). Após termos relembrado rapidamente alguns elementos centrais dos debates que opunham os defensores dos direitos divinos dos reis aos teólogos papistas, a crítica de Filmer não chega a nos causar surpresa. Também não nos surpreenderá encontrarmos na Defensio Fidei (doravante DF) a defesa de direitos naturais inatos que todos os seres humanos possuem por terem sido criados por Deus, bem como a defesa da origem democrática do poder civil fundada nas teses da igualdade e liberdade natural dos seres humanos. De fato, o pensador jesuíta já havia articulado essas teses no Tractatus de Legibus ac Deo Legislatore, pois era exatamente nessa obra que Suárez trabalhava quando é solicitado a defender a causa papal.

O Tratado acerca das leis e do Deus legislador (doravante DL) inicia delimitando as pretensões de seu autor em direção ao que poderíamos chamar de um projeto de teologização do campo jurídico que deveria, por seu turno, conduzir à teologização parcial do político. Trata-se, portanto, também nesse caso, de um projeto tipicamente pós-tridentino. As razões que embasariam tais pretensões são apresentadas desde a abertura da obra, pois, em seu prefácio, Suárez deixa claro que a busca de Deus não é apenas o fim último da criatura racional, mas que essa busca é orientada em sua consecução pelo próprio Deus. Ele apontaria os caminhos e serviria de guia para a criatura racional. E se isso é assim, continua, o teólogo não poderia não incluir entre seus afazeres o estudo das leis, sendo portanto este domínio abarcado pelo da teologia, na medida em que cabe a essa ciência o estudo das coisas divinas e da felicidade junto a Deus.

Dado, então, que o modo como ocorre a salvação repousa nas ações livres e na retidão moral, a qual, por sua vez, depende em grande parte da lei enquanto medida das ações humanas, segue-se que os estudos das leis se torna uma divisão importante da teologia; e quando a sagrada ciência aborda a lei, ela seguramente toma por objeto o próprio Deus enquanto Legislador (DL, I, 1).

${ }^{7}$ Para o debate Filmer e Suárez, veja-se: (SOMMERVILLE, 1982 e WARD, 2004). 
Contra aqueles que gostariam de ver os limites da teologia circunscritos ao domínio das leis divinas, delegando ao filósofo moral e aos juristas o trato das leis humanas, Suárez reivindica poder argumentar de forma expeditiva, uma vez que não parece razoável supor que as condutas humanas guiadas pela lei humana não influenciariam no alcance da felicidade. E se é verdade que influenciam, devem poder ser escrutinadas pela teologia. Ademais, é função da teologia considerar a consciência dos homens nessa vida, pois a retidão da consciência repousaria na observância das leis, uma vez que toda lei é uma regra que leva à salvação eterna, se obedecida, ou, caso violada, a sua perda. Assim, o estudo da lei, enquanto obrigando a consciência, pertence ao domínio da teologia. $\mathrm{E}$ isso aplica-se tanto ao caso das leis divinas, quanto ao da lei natural, na medida em que essa estabelece proibições, ordens e permissões. Mostraria ainda a teologia em que medida devemos nos submeter a poderes superiores e dá as razões para observarmos as leis eclesiásticas e seculares. De modo mais geral, pode-se dizer que, a partir dos fundamentos da fé, o teólogo deve deduzir o que deve estar presente e ser mantido nos ordenamentos jurídicos.

O núcleo da argumentação repousa nas noções de consciência e obrigação. Se ser obrigado é estar vinculado a uma regra dada à consciência e se as regras podem ser tanto sobrenaturais, naturais ou civis, então as modalidades como a obrigação ocorre revelam o vínculo da consciência com essas regras por meio de uma hierarquia. As regras civis passam a fazer parte do campo de investigação da teologia justamente por procurarem estabelecer obrigações aos seres humanos, as quais devem estar subordinadas às das leis naturais. Numa palavra, seria função da teologia verificar se as obrigações impostas civilmente coadunamse com as obrigações da consciência cristã. Como diz mais uma vez o De Legibus:

A teologia claramente revela a maneira pela qual todas as leis são padrões da ação humana relativamente à consciência (ad conscientiam) e assim revela também em que medida condizem ao mérito ou demérito da vida eterna (DL, I, 2).

A noção de consciência, central para os autores do período, adquire no pensamento de Francisco Suárez a função de delimitadora dos deveres imponíveis aos súditos cristãos. No livro III, cap. 21, do De Legibus, Suárez enfatizará o ponto por meio da distinção entre os dois tipos de fora. O forum externum, será o lugar das obrigações civis e eclesiásticas ao passo que o forum internum será definido justamente como o fórum da consciência, interior à mente do homem e sede das obrigações para com Deus.

Tentando ser um pouco mais preciso acerca das relações entre teologia e política, poderíamos dizer, empregando um vocabulário que não é propriamente o do autor, que Suárez compreende os direitos e obrigações naturais e, por via de consequência, as noções de liberdade e igualdade, como fundadas na natureza humana criada por Deus. Isso não significa, todavia, que todos os direitos e obrigações políticas sejam redutíveis a direitos e obrigações naturais. Podem existir obrigações políticas compatíveis com as obrigações naturais que as ampliem ou mesmo limitem, mas sem as contradizer. Nas palavras de Schaffner, Suárez inferiria "da separação dos fins da Igreja e do Estado, que a Igreja detém um poder indireto sobre o estado, ela não teria jurisdição direta em matérias temporais que digam respeito ao cidadão qua cidadão. As autoridades estatais gozariam de uma soberania relativa na ordem temporal no que toca à justiça e à paz terrenas. A Igreja poderia apenas interferir quando os governantes atentassem contra seus próprios bens espirituais ou contra os dos cidadãos" (SCHAFFNER, 2016, p. 67-68). A exigibilidade de obrigações jurídicas imponíveis pelo aparato estatal seria, nessa medida, controlada pelas obrigações exigíveis do cidadão cristão. Essa é certamente uma maneira um tanto quanto enviesada de dizer que leis emanadas pela autoridade política são delimitadas, mas não redutíveis, a direitos e obrigações naturais, entendendose por natural as obrigações impostas por Deus à consciência.

O primeiro livro do DL inicia com a caracterização de dois elementos básicos, a saber com a caracterização das noções de lei - lex (capítulo 1) e direito - ius (capítulo 2), aborda ainda os vínculos entre essas noções para que se possa, posteriormente, determinar os tipos de leis e direitos existentes. A despeito da grande 
e inegável influência dos escritos de Tomás de Aquino em autores da Península Ibérica, a tal ponto desse período ser denominado por Skinner como "A retomada do tomismo", o certo é que Suárez vai afastar-se do pensamento de Tomás tanto em sua caracterização da lei quanto da do direito. Vejamos.

Começando pela lei, Suárez recusa a seguinte definição proposta por Tomás na Suma de Teologia (I-II, q. 90, a. 1): "A lei é uma certa regra e medida da ação pela qual alguém é levado a agir ou a refrear o agir". Essa definição seria problemática, primeiramente por ser demasiadamente ampla, aplicando-se mesmo a criaturas não racionais. ${ }^{8}$ Em segundo lugar, ela não seria suficientemente discriminatória de preceitos morais, pois aplica-se a qualquer regra de conduta sem conteúdo moral, como regras para confecção de artefatos. Ademais, e essa seria a razão principal razão para a sua recusa, mesmo conselhos, ou seja, meros indicativos de conduta, mas sem força obrigatória, deveriam ser classificados como leis.

Baseado em obras de Platão que começaram a circular desde o final do século XV, como as Leis e o Górgias, Suárez procurará, então, oferecer uma caracterização mais restrita de lei que se aplicará a assuntos morais. Essa seria:

A lei é uma certa medida dos atos morais na medida em que tais atos são dotados de retidão moral (rectitudinem moralem) por estarem conformes a ela e, se dela discordarem, são tortuosos (obliqui). DL, I, 2.

Dessa caracterização, segue-se uma conclusão evidente que será extraída diversas vezes ao longo do tratado: ainda que preceitos torpes possam ser, e frequentemente o são, designados como leis, estritamente falando, "apenas aquilo que é medida da retidão de forma absoluta (simpliciter) e, portanto, somente aquela que é a regra reta e honesta, pode ser chamada lei” (DL, I, 2). As regras iníquas são designadas leis apenas por analogia. Podemos exprimir o ponto com o auxílio de um outro vocabulário dizendo que a observância a critérios morais é condição de existência da lei na medida em que aquilo que não obriga a consciência carece de força cogente e, sem força cogente, não pode ser lei. Seriam talvez apenas regras postas por um legislador positivo, mas desprovidas de força obrigatória frente à consciência.

Antes de prosseguir, cabe uma pergunta. Não estaria essa definição de lei sendo demasiadamente restritiva a ponto de obrigar-nos a rever a caracterização entre os poderes civis e da Igreja anteriormente exposta? Isso porque, por um lado, afirmamos acima que direitos e obrigações políticas são delimitadas, mas não redutíveis, a direitos e obrigações naturais. Por outro, a definição mesma de lei parece exigir algo mais forte, a saber; a força cogente da legislação para apresentar-se frente à consciência humana.

Suárez resolve a dificuldade reconhecendo que as leis humanas também estabelecem obrigações à consciência. Todavia, essa obrigação (como fica claro no DL, III) é um efeito da lei natural. A obrigação na consciência pode ser, portanto, ou um efeito imediato e essencial da lei natural ou pode ser um efeito remoto que, por sua vez, pode ser essencial ou acidental. A raiz do problema estaria aparentemente no fato de que a vontade arbitrária do legislador civil estaria entre os elementos constituidores das obrigações criadas pela lei positiva. Todavia, continua Suárez, a introdução da vontade do legislador civil não impede que a obrigação civil seja um efeito da lei natural, da mesma forma que as obrigações assumidas por atos voluntários pessoais de promessa não impede a existência de obrigações advindas da promessa. Talvez um exemplo possa ajudar a explicar esse ponto. Quando uma lei estipula o preço a ser pago por um produto, surge a obrigação de justiça de respeitar o preço, sendo o seu desrespeito visto como um ato de violação da obrigação natural de não roubar. A obrigação de respeitar o preço legal e positivamente estabelecido pela vontade do legislador civil obriga a consciência e seu desrespeito acaba por redundar em uma violação de uma obrigação natural.

8 Para uma análise mais detalhada, consulte-se: (BRITO VIEIRA, 2008). 
O segundo conceito central a ser visto é o de ius. Suárez afasta-se novamente de Tomás de Aquino nesse ponto. Na verdade, afasta-se mais radicalmente na caracterização desse segundo do que na do primeiro, mas o faz de forma pouco saliente, pois faz questão de aproximar suas definições da de Tomás, mesmo havendo grande distância entre ambas. Ius, diz Suárez, é um termo equívoco.

Algumas vezes, ius significa a faculdade moral para adquirir ou reter algo, seja um domínio completo ou alguma participação nele, e esse ius é dito, como aprendemos com S. Tomás, o objeto próprio da justiça (DL, III, 17).

Esse seria o sentido principal e por ele o proprietário é dito ter direito sobre uma coisa ou é dito ter direito sobre algo que lhe é devido e o trabalhador é dito ter direito sobre o seu salário. Ele pode convenientemente ser designado direito real ou direito útil. "Outras vezes, ius significa a lei (lex), que é a regra da conduta honesta e, nesse sentido, estabelece uma certa equidade nas coisas e é a expressão do ius tomado no primeiro sentido" (DL, III, 17). É chamado direito legal ou direito honesto. Cabe enfatizar aqui ser o direito real anterior ao direito legal justamente porque o real é a ratio legis, a razão do legal.

A próxima pergunta que Suárez se coloca é a da necessidade de leis. Absolutamente falando, leis não são necessárias, pois o único ser necessário é Deus e ele não está sujeito a leis. Leis somente existem na suposição da existência de seres racionais que possuem sua conduta orientada em direção a certo fim. Mas por que o ser humano necessitaria de leis? A resposta residiria na natureza da criatura racional. A lei é imposta apenas para uma natureza que é livre e que possui por objeto ações livres. Uma criatura racional, em virtude do fato mesmo de que ela é um ser criado, possui um ser superior a cuja providência e controle está submetida, pois, por ter uma natureza intelectual, ela é capaz de estar submetida a um governo moral que a guia através de um comando (imperium).

No entanto, não basta apenas provar que a criatura racional pode estar submetida a leis. É preciso mostrar ainda que ela necessariamente está submetida e isso Suárez o faz mostrando que, por ter sido criada do nada, ela necessita de critérios para saber o que é bom e o que não o é. Esses critérios precisam lhe ser dados para que ela possa viver conforme a sua natureza. De modo converso, diz Suárez, aquele que não está submetido à lei não pode pecar, mas uma criatura racional possui o poder de pecar e, portanto, ela está necessariamente submetida à lei. Isso equivale a dizer que o erro somente pode ser entendido por referência a padrões que estabelecem o que é o correto. Na ausência de tais padrões, não somente nenhum comportamento seria visto como errôneo, mas também nenhuma finalidade poderia ser posta como objetivo a ser alcançado. Leis, tanto as instituídas por Deus quanto às instituídas pelos homens, são introduzidas justamente para fornecer padrões que determinem meios para alcançar certos fins, discriminando os meios adequados dos inadequados.

Seguindo em parte o Tratado da lei de Tomás de Aquino, os autores do período apresentam a seguinte tipologia das leis:

Lex aeterna $=$ aquela pela qual Deus age, pois é a expressão da sua vontade

Lex divina $=$ revelada por Deus e presente nas Sagradas Escrituras

Lex naturalis = posta por Deus na consciência dos seres humanos para que eles possam reconhecer seus desígnios e saber como atingir seu fim

Lex humana $=$ criadas pelos seres humanos para dirigirem os assuntos de suas comunidades

A pergunta óbvia a ser feita seria a seguinte: como compreender essa tipologia à luz da tese segundo a qual leis expressam direitos? A pergunta revela-se particularmente interessante no momento de determinar 
o local a ser ocupado pelos direitos dos povos, ius gentium. ${ }^{9}$ De início, lembremos que Tomás de Aquino aborda esse tema na Suma de Teologia retomando uma certa ambiguidade presente no início do Digesto. Com efeito, as fontes romanas atribuem ao jurista Ulpiano uma concepção tripartite do direito e ao jurista Gaio uma concepção bipartite. Assim, segundo Ulpiano, o direito dividir-se-ia em:

Ius naturalis = comum aos seres humanos e animais

Ius gentium $=$ comum a todos os povos

Ius positivum = particular a cada associação política

Ao passo que para Gaio, a distinção comportaria apenas:

Ius naturalis $=$ ius gentium $=$ comum a todos os povos

Ius positivum = próprio a cada povo

Essa ambiguidade, presente no Digesto, revelar-se-á bastante profícua para Tomás, pois permitirá distinguir dois momentos distintos e sucessivos: 1) o estágio anterior à instauração das comunidades políticas, estágio descrito como condição natural dos seres humanos nascidos iguais e compartilhando a posse de todos os bens; 2) o momento de instauração das associações políticas a qual traria consigo a necessidade de criação de regras de cooperação social, como a instauração da propriedade privada e da escravidão. Seriam precisamente essas regras criadas no momento de criação das associações políticas que configurariam o ius gentium, o direito dos povos.

A propriedade privada seria, para Tomás de Aquino, um procedimento adotado por todos os povos por revelar-se o melhor meio de administração de bens, na medida em que cada um administraria melhor o que lhe é próprio. A escravidão, por sua vez, teria sido adotada pelos povos por permitir que aqueles que não estão em condições de conduzir por si mesmos suas vidas fossem conduzidos por outros que sobre eles possuem autoridade. Em suma, do ponto de vista do direito natural, todos os seres humanos seriam livres e iguais e compartilhariam a posse de todos os bens. A propriedade privada e a escravidão teriam sido introduzidas pelo direito dos povos.

Essa solução, no entanto, traz consigo diversos problemas, alguns deles apontados por Suárez. Um deles diz respeito à escravidão. Para sustentar a igualdade natural de todos os seres humanos, Tomás vêse obrigado a deslocar o problema da escravidão para o âmbito do direito dos povos, mas isso implica não somente que a escravidão está constantemente presente em toda forma de associação política como também que ela é inerente ao processo mesmo de constituição dessas associações. Malgrado a pretensa defesa da igualdade natural de todos os seres humanos, o modelo de Tomás conduziria, ao fim e ao cabo, a uma justificação bastante radical do instituto da escravidão.

Suárez afastar-se-á radicalmente dessa posição e o fará ao considerar que o critério último a ser empregado na classificação das leis é a natureza próxima do legislador. A lei seria a expressão de um ato de vontade do legislador que manda agir observando sua vontade. As leis eterna, divina e mesmo a natural seriam,

${ }^{9}$ Para o contexto do debate, veja-se: (OLIVEIRA E SILVA, 2011 e 2014). 
assim, a expressão da vontade do Deus legislador (e por isso o título da obra).Já o direito humano teria na vontade próxima dos seres humanos a sua fonte, entendendo-se por próximo o qualificativo que permite reduzir a fonte de toda lei, em última instância, à vontade divina. De posse desse critério, Suárez irá então redefinir o ius gentium como um direito positivo humano ao afirmar que:

Os preceitos do ius gentium foram introduzidos pela vontade livre e pelo consentimento da humanidade, seja essa toda a humanidade ou a sua maior parte. Logo, eles não podem ter sido escritos no coração dos homens pelo Autor da Natureza. Portanto, eles pertencem à lei humana e não à lei natural (DL, II, 17).

A força do gesto de Suárez está em que, a um só tempo, ele rompe com a autoridade presente no texto do Digesto e toma distâncias para com a autoridade de Tomás de Aquino. Rompe com o Digesto na medida em que é explicitamente negada a identidade, propagada por Gaius, entre direito natural e direito dos povos. Afasta-se de Tomás, por sua vez, ao recusar a interpretação do ius gentium como, em última instância, uma forma de direito natural, pois os preceitos do direito dos povos seriam necessários e presentes em toda forma de associação política. São muitas as consequências a tirar desse gesto, mas precisamos chamar a atenção para uma em especial, a saber: o estatuto da escravidão. Percebe-se claramente, na argumentação de Suárez, um deslocamento semântico que retira os preceitos do ius gentium da categoria de leis e os reinterpreta como meros costumes, ou melhor, como práticas costumeiras aceitas e compartilhadas pela maioria dos povos, mas não necessariamente pela totalidade, de tal sorte que essas práticas, ainda que convenientes em alguns casos, não seriam nem necessárias nem universais. Diz Suárez:

\begin{abstract}
A lei humana é dupla: escrita e não escrita (...).É manifesto que o ius gentium não é escrito e que, portanto, difere com respeito a isso da lei civil. (...) Ademais, a lei não escrita é feita de costumes e, caso tenha sido introduzida pelos costumes de uma nação particular, é vinculante apenas da conduta daquela nação e chama-se lei civil. Se, por outro lado, foi introduzida pelos costumes de todas as nações e, assim, obriga a todas, acreditamos tratar-se do ius gentium propriamente falando. Esse sistema difere, portanto, do da lei natural por estar baseado no costume e não na natureza (DL, II, 19).
\end{abstract}

Abre-se assim a possibilidade de tratarem-se diversas práticas costumeiras que regulam as relações entre povos, seja elas diplomáticas, como o uso de embaixadores, comerciais, como os contratos entre comerciantes de diversos povos que não necessitam ater-se a todas as formalidades da lei civil, ou os costumes que regulam as práticas em casos de guerra. Logo, a conclusão de Suárez:

Na mesma classe, coloco a escravidão (servitutes). Pois os povos e nações em suas relações recíprocas instituíram leis sobre a escravidão, embora essa instituição não fosse necessária do ponto de vista da razão natural (DL, II, 19).

\title{
4. A origem do poder civil
}

Podemos agora passar ao tema da origem democrática do poder civil. O problema é posto mais claramente, como já dissemos, na obra Defesa da Fé Católica e Apostólica contra os erros da Seita Anglicana. ${ }^{10}$ O ponto de partida é uma clarificação do significado da tese enunciada por James I, pois, como já deve ter ficado claro pelo que já foi visto até o momento, o próprio Suárez deve reconhecer a verdade da afirmação segundo a qual todo poder provém de Deus. Essa afirmação pode e deve ser entendida, todavia, em dois sentidos, a saber, como afirmando que todo poder tem em Deus sua causa última ou que tem em Deus sua causa próxima. No primeiro sentido, ela está correta. No segundo, precisamente o sentido reivindicado por James I, ela é falsa. Afirma Suárez:

Isto porque não há poder (potestas) algum que não proceda de Deus desta maneira, enquanto causa primeira, e, portanto, diretamente nesse mesmo sentido. Por conseguinte, o poder dado diretamente pelos homens, o rei ou

\footnotetext{
${ }^{10}$ Sobre as mudanças de posição do autor em ambas as obras, consulte-se os estudos reunidos em: (MERÊA, 2003, em particular páginas 80-86).
} 
o pontífice, é dado também por Deus enquanto causa primeira (...) Contudo, tal poder não se diz simplesmente provir de Deus de maneira direta, mas apenas segundo um certo sentido, pois é dado imediatamente pelo homem e depende dele (DF, 246).

Para melhor circunscrever o âmbito do problema, Suárez inicia estabelecendo uma série de distinções. Primeiramente, apelando à distinção entre potestas e potentia, ${ }^{11}$ Suárez distingue dois modos pelos quais Deus pode conferir poder (potestas) diretamente, isto é, por meio de sua vontade e potência (potentia). O primeiro é um poder (potestas) que, dada a natureza da coisa, está necessariamente ligado à alguma natureza criada pelo próprio Deus, e. g.: a) ao criar a alma, Deus confere a ela as potências (potentiae) a ela ligadas; b) ao criar seres humanos capazes de se reproduzirem, Deus atribui poderes aos pais sobre filhos, de tal modo que o poder (potestas) moral do pai sobre o filho é conferido por Deus. ${ }^{12}$ Esse seria precisamente o tipo de poder que James I reivindica, sem, aos olhos de Suárez, conseguir prová-lo. O segundo modo de atribuição de poder por Deus ocorreria de maneira direta e por uma doação especial, sem a interferência de uma criação, e. g.: o poder (potestas) conferido a Pedro.

A segunda dessa série de distinções diz respeito ao sujeito que é dito receber o poder. Pode-se considerar o poder enquanto está ou pode estar em todo corpo político da comunidade humana ou do Estado ou enquanto existe ou pode existir nos membros que formam a comunidade. $O$ poder pode, ainda, ser considerado em si mesmo e em abstrato ou enquanto particularizado em uma das espécies de regime político tradicionalmente aceitas (monarquia, um só soberano, aristocracia, onde há uma assembleia ou tribunal, ou democracia, constituída pelos votos (suffragia) de todo o povo) ou nas demais formas mistas ou delas derivadas. Podemos, agora, resumir a sequência do argumento de modo rápido. Suárez simplesmente nega a doação direta do poder a algum soberano, pois não há evidência alguma disso ter ocorrido. Segue-se, portanto, que o poder reside não em alguém em particular, mas na própria congregação política.

Já o DL, III, 4 adverte que uma comunidade humana pode ser entendida em dois sentidos. Por um lado, é apenas um agregado (aggregatum), quando não há vínculo que una seus membros e nesse sentido não se tem um corpo político. Por outro, quando a multidão de homens por uma vontade especial ou consenso comum reúne-se em um corpo político (corpus politicum) único unidos pelo vínculo social de ajuda mútua

\footnotetext{
${ }^{11}$ Em latim clássico, o termo potestas era usado para referir-se à autoridade legítima ao passo que potentia era usado para não fazer referência a direitos. Sobre a evolução da terminologia entre autores jesuítas, vide: (HÖPFL 2004, pp. 186 e ss). Sobre a distinção entre potestas ordinaria e delegata, vide: (DL, III, 4). Para a tradução inglesa da passagem, consulte-se: (KRAYE 1997, p. 42-43).

${ }^{12}$ Sobre a maneira como os jesuítas entendiam o poder do paterfamílias, consulte-se: (HAAR, 2019).
} 
para um fim político forma-se um corpo místico (corpus mysticum) que pode ser moralmente dito único e exige uma cabeça única. ${ }^{13}$ Logo, há somente uma consequência possível:

Com efeito, por os homens se congregarem numa só cidade ou Estado, surge tal poder naquela comunidade sem a intervenção de alguma vontade criada, e com uma necessidade tamanha que não pode ser impedida pela vontade humana $(D F, 249)$.

Não há como criar um corpo político sem lhe atribuir poder sobre seus membros. Em outras palavras, a decisão de constituir um corpo político é um ato de vontade da coletividade. Mas não faz sentido tentar criar um corpo político que não disponha de poder, pois o poder faz parte de sua natureza. Isso não é, no entanto, o mesmo que afirmar que o governo político está naturalmente concentrado nas mãos de um governante. Não há nada na razão natural que conduza nessa direção, restando, portanto, como única forma de regime possível o democrático. Isso não significa, todavia, que outro regime além do democrático não seria possível. A conclusão é mais fraca:

A democracia, todavia, poderia existir sem uma instituição positiva, apenas por uma instituição ou dimanação natural, com a negação apenas de uma instituição nova ou positiva, pois a própria razão natural estabelece que o poder político supremo segue-se naturalmente da comunidade humana perfeita e que, por esse motivo, pertence a toda a comunidade, exceto se for transferido para outro por via de uma nova instituição (DF, 251).

Podemos concluir dizendo que a defesa da necessária origem democrática do poder civil não termina com a caracterização do poder civil, mas prossegue em direção ao modo como o poder monárquico poderia ser originado. Em outras palavras, por quais processos são constituídas comunidades políticas e por quais modalidades poderia ocorrer o assentimento que transfere o poder da comunidade para $o$ monarca. Suárez basicamente reconhece três possibilidades que seguem na verdade modelos tradicionais.

1. O processo histórico de criação de uma cidade, que vai desde as primeiras associações de pessoas em uma e depois diversas células familiares até a cidade completa, traz consigo um consentimento expresso ou tácito de atribuição de poder ao chefe de família ou da aldeia até formar-se a figura do monarca;

2. Um segundo processo que seria o do consentimento direto no qual a totalidade do povo reunida escolhe um soberano e, uma vez realizada essa escolha, ela poderia prosseguir sem a necessidade de nova eleição, bem ao estilo previsto no Digesto;

\footnotetext{
${ }^{13} \mathrm{O}$ modo como essa união de vontades converge para a formação do corpo místico tem sido matéria de controvérsias entre intérpretes, particularmente após a interpretação de Skinner que via em Suárez um defensor de uma forma de contratualismo. Em sua seminal obra sobre as fundações do pensamento político moderno, Skinner salientou que um dos principais aspectos da compreensão que os tomistas do século XVI tinham acerca da lei natural estava ligado ao objetivo de "refutar a convicção herética de que o estabelecimento da sociedade política é diretamente ordenado por Deus" (SKINNER, 1999, p. 432). Buscavam assim estabelecer que "nenhuma república possui uma existência natural" e que foram "deliberadam ente criadas" tendo como ponto de partida um estado natural imaginário. Esse status naturae, segundo a expressão que Skinner encontra na obra do jesuíta espanhol Luís de Molina (1535-1600), seria definido como um "estado de liberdade, igualdade e independência" (SKINNER, 1999, p. 433). A liberdade seria consequência direta do fato de todos os seres humanos nascerem livres e que, para empregar a expressão de Francisco de Vitória (1483-1546) citada pelo historiador inglês, antes de serem estabelecidas repúblicas "nenhum homem era superior a todos os outros" (SKINNER, 1999, p. 433). Tampouco haveria, portanto, direitos de propriedade (dominium) ou jurisdição política de uma pessoa sobre outra. A tese segundo a qual a condição humana natural seria uma condição social, mas não política, teria sido endossada por diversos pensadores jesuítas, mas teria sido Suárez quem especialmente defendeu que "se houvéssemos continuado a viver em nossas comunidades naturais e pré-políticas, sem nos submeter aos ditames do direito divino, em pouco tempo nossa vida se veria degradada por crescente injustiça e incerteza" (SKINNER, 1999, p. 436). Sem entrarmos nos meandros desse debate, preferimos acompanhar posições como as de (CAMPOS, 2019) que encontram em Suárez no máximo um 'proto-contratualista' ao mesmo tempo que ressaltam que o contexto das polêmicas nas quais as obras foram escritas deixam perceber como a legitimidade do poder civil não pode ser garantida sem o consentimento de seus participantes.
} 
3. Um terceiro modo que seria o das guerras de conquista que podem ser justas ou injustas. Se justas, o príncipe vencedor adquire o verdadeiro direito e domínio sobre o reino, o que não seria surpreendente. E mesmo o consentimento alcançado em uma guerra injusta acabaria por redundar em uma transferência legítima do poder.

Não temos condições de analisar em maiores detalhes essas teses. Gostaríamos, no entanto, de concluir com uma passagem de Suárez que tem um tom quase que irônico se comparada com a atitude dos jesuítas frente a submissão das populações indígenas pelo medo e pela força.

\begin{abstract}
Contudo, acontece com frequência um reino ser ocupado por via da guerra injusta, maneira pela qual se ampliaram em geral os mais célebres impérios do mundo. Em tal caso, não ocorre de início qualquer verdadeira aquisição do reino nem do poder por faltar um justo título; porém, acontece que, ao decorrer algum tempo, o povo vem a consentir livremente ou os reis sucessores vêm a reinar de boa fé, cessando então a tirania e começando o verdadeiro poder e autoridades régias. Assim se obtém sempre o poder diretamente por meio de algum título humano ou por vontade humana $(D F, 258-259)$.
\end{abstract}

\title{
Referências bibliográficas
}

BELLARMINE, R. (1721). De Laicis. In: De controversiis christianae fidei adversus hujus temporis. Praga: Wolffgang Wickhart.

BELLARMINE, R. (2012). On Temporal and Spiritual Authority. On Layman or Secular People. On the Temporal Power of the Pope. Against William Barclay. On the Primary Duty of the Supreme Pontiff. Edited, translated, and with an introduction by Stefania Tutino. Indianapolis: Liberty Fund.

BOURDIN, B. (2015). La genèse théologico-politique de l'État moderne. Paris: PUF.

BRITO VIEIRA, M. (2008). Francisco Suárez and the "Principatus Politicus". History of Political Thought, v. 29, n. 2, pp. 273-294.

DECOCK, W. (2011). "From Law to Padise: Confessional Catholicism and Legal Scholarship". Rechtsgeschichte. Zeitschrift des Max-Plack-Instituts für europäische Rechtsgeschichte. Frankfurt, v. 18, pp. 11-34.

DECOCK, W. (2012). Theologians and Contract Law: The Moral Transformation of the "Ius Commune" (ca. 1500-1650). Leiden: Brill.

FASTIGI, R. L. (2014). “Francisco Suárez as Dogmatic Theologian”. In: SALAS, V. M. and FASTIGI, R. L. A Companion to Francisco Suárez. Leiden: Brill, pp. 148-163.

FILMER, R. (1949). Patriarcha and Other Political Works of Sir Robert Filmer. Edited from the original sources and with the introduction by P. Laslett. Oxford: Blackwell.

GUY, N. (2020). Finding Locke's God. The Theological Bases of John Locke's Political Thought. London: Bloomsbury Academic.

HAAR, C. P. (2019). Natural and Political Conceptions of Community. The Role of the Household Society in Early Modern Jesuit Thought, c. 1590-1650. Leiden: Brill.

HÖPFL, H. (2004). Jesuit Political Thought. The Society of Jesus and the State, c. 1540-1630. Cambridge: Cambridge University Press. 
JAMES VI \& I. (2012). The Workes of the Most High and Mightie Prince, Iames, by the Grace of God, King of Great Britaine, France and Ireland, Defender of the Faith, b'c. An Unabridged Facsimile of the 1616 Edition Including the Two Workes Appended in 1620. Laurel: Miscellany Press.

KRAYE, J. (1997). Cambridge Translations of Renaissance Philosophical Texts. Volume 2: Political Philosophy. Cambridge: Cambridge University Press.

LEITE, E. (2002). Conscience and Casuistry in Early Modern Europe. Cambridge: Cambridge University Press.

LOCKE, J. (1998). Dois Tratados sobre o Governo. Tradução de Júlio Fischer. São Paulo: Martins Fontes.

MÄKINEN, V. (2018). “The Evolution of Natural Rights, 1100-1500”. In: KORKMAN, P. e MÄKINEN, V. Universalism in International Law and Political Philosophy. Helsinki: Helsinki Collegium for Advanced Studies, pp. 105-119.

MERÊA, P. (2003). Sobre a origem do pode civil. Estudos sobre o pensamento político e jurídico dos séculos XVI e XVIII. Introdução e seleção M. N. de Brito. Coimbra: Itinerários.

McILWAIN, C. H. (1918). The Political Works of James I. Reprinted from the Edition of 1616, with an Introduction. Cambridge: Harvard University Press.

NORTH, M. L. (2012). “Anonymity's Subject: James I and the Debate over the Oath of Allegiance." New Literary History. Baltimore, v. 33, n. 2, pp. 215-232.

PROSPERI, A. (1996). Tribunais da consciência. Inquisidores, confessores e missionários. Tradução de H. F. de Andrade. São Paulo: Edusp.

OLIVEIRA E SILVA, P. (2011). "A fundamentação, natural ou positiva, do direito das gentes em alguns comentários seiscentistas à Suma de Teologia de Tomás de Aquino". Aquinate, n. 14, pp. 31-50.

OLIVEIRA E SILVA, P. (2014). "Facing the Ambiguities of Aquinas: The Sixteenth-Century Debate on the Origin of ius gentium." In: SPEER, A. and GULDENTOPS, G. Das Gesetz - The Law - La Loi. Berlin-Boston: De Gruyter, pp. 489-508.

SCHAFFNER, T. (2016). "Is Francisco Suárez a Natural Law Ethicist?" In: SIMMERMACHER, D. et alii. The concept of Law (lex) in the Moral and Political Thought of the 'School of Salamanca'. Leiden, Brill.

SKINNER, Q. (1999). As fundações do pensamento político moderno. Tradução R. J. Ribeiro e L. T. Motta. São Paulo: Companhia das Letras.

SOMMERVILLE, J. P. (1982). "From Suarez to Filmer: A Reappraisal”. The Historical Journal. Cambridge, v. 25, n. 3, pp. 525-540

STORCK, A. (2019). "A recepção da Política de Aristóteles na Nova Espanha: Alonso de la Vera Cruz e o seu Speculum Coniugiorum (1556)." Revista Veritas. Porto Alegre, v. 64, n. 3, JUL.-SET. 2019, pp. 1-26.

SUÁREZ, F. (1872a). Defensio Fidei Catholicae et Apostolicae Adversus Anglicanae Sectae Errores. Napoli: Ex Typis Fibrenianis.

SUÁREZ, F. (1872b). Tractatus de Legibus ac Deo Legislatore in Decem Libros Distributos. Napoli: Ex Typis Fibrenianis. 
SUÁREZ, F. (1944). Selections from Three Works of Francisco Suárez, S.J. Diversos tradutores. Oxford: Clarendon Press.

SUÁREZ, F. (2015). "Defesa da Fé Católica e Apostólica contra os Erros da Seita Anglicana, Livro III, capítulos II, III e IV e Livro VI, capítulo IV”. Tradução de Campos, A. S. In: CALAFATE, P. A Escola Ibérica da Paz nas Universidades de Coimbra e Évora (Séculos XVI e XVII). Vol. 2: Escritos sobre a justiça, o poder e a escravatura. Coimbra: Almedina.

TUTINO, S. (2007). Law and Conscience. Catholicism in Early Modern England, 1570-1625. Oxford: Routledge.

TUTINO, S. (2010). Empire of Souls. Robert Bellarmine and the Christian Commonwealth. Oxford: Oxford university Press.

WAELKENS, L. (2015). Amne adverso. Roman Legal Heritage in European Culture. Leiden: Leiden University Press.

WARD, L. (2004). The Politics of Liberty in England and Revolutionary America. Cambridge: Cambridge University Press.

WOOTON, D. (2003). Divine Right and Democracy. An Anthology of Political Writing in Stuart England. Edited with and Introduction, by D. Wootton. Cambridge: Hackett Publishing Company. 